A $\underset{\text { publications }}{\mathrm{C}}$ Rec. Nat. Prod. 15:6(2021) 487-502

records of natural products

\title{
Secondary Metabolites from Teucrium creticum L.
}

\section{Azmi Hanoğlu $\oplus^{1}$, Duygu Yiğit Hanoğlu $\oplus^{2}$, Nilay Demirel $\oplus^{1}$,} Hasan Soliman Yusufoğlu $\oplus^{3}$ and İhsan Çalış $\oplus^{1^{*}}$

\author{
${ }^{I}$ Near East University, Faculty of Pharmacy, Department of Pharmacognosy, Lefkoşa, \\ Turkish Republic of Northern Cyprus \\ ${ }^{2}$ Near East University, Faculty of Pharmacy, Department of Pharmaceutical Botany, Lefkoşa, \\ Turkish Republic of Northern Cyprus \\ ${ }^{3}$ Prince Sattam Bin Abdulaziz University, Department of Pharmacognosy, Al-Kharj-11942, Saudi
} Arabia

(Received December 29, 2020; Revised February 25, 2021; Accepted March 01, 2021)

\begin{abstract}
From the aerial parts of Teucrium creticum L. (Lamiaceae) eight compounds, $\mathbf{1}-\mathbf{8}$ were isolated using chromatographical methods. Based on the results of spectroscopical analysis such as UV, 1D-NMR $\left({ }^{1} \mathrm{H}-\right.$, $\left.{ }^{13} \mathrm{C}-\mathrm{NMR}, \mathrm{DEPT}-135\right), 2 \mathrm{D}-\mathrm{NMR}$ (COSY, HSQC, HMBC, NOESY) and HRMS, the structure of the compounds were determined as two iridoids, 8- $O$-acetylharpagide (1) and teuhircoside (2), two phenylethanoid glycosides, verbascoside (= acteoside) (3) and lavandulifolioside (4), and four neoclerodane-type diterpenoids, teucrin $\mathrm{H} 3$ (= 19-acetylgnaphalin) (5), teucjaponin B (6), teucretol (7) and diacetylteumassilin (8).
\end{abstract}

Keywords: Lamiaceae; Teucrium creticum; iridoids; phenylethanoid glycosides; neo-clerodane-type diterpenoids.@ 2021 ACG Publications. All rights reserved.

\section{Introduction}

Lamiaceae, the sixth largest Angiosperm family, contains more than 245 genera and 7886 species, and it is distributed worldwide for numerous species economically and medicinally valued [1]. In the last two decades, an improvement has been presented for its subfamilial classification [2]. According to the recent reports, Ajugoideae, Lamioideae, Nepetoideae, Prostantheroideae, Scutellarioideae, Symphorematoideae, Viticoideae, Cymarioideae, Peronematoideae, Premnoideae, Callicarpoideae and Tectonoideae have been recognized as subfamilies of Lamiaceae. Throughout the world, in the family Lamiaceae, Teucrium L. is one of the largest genera with 250 species. In the flora of Turkey, five subfamilies of Lamiaceae are to be found: Ajugoideae, Lamioideae, Nepetoideae, Scutellarioideae and Viticoideae. As a member of Ajugoideae, Teucrium genus is represented by 49 taxa in the flora of Turkey [1].

In the flora of Cyprus, Teucrium is represented by 9 species which are classified under the five sections, Teucrium (1 spec.), Polium (5 spec.), Chamaedrys (1 spec.), Scorodonia (1 spec.) and Scordium (1 spec., 2 ssps.) [3]. Present study has been performed on the Teucrium creticum L. which is a member of Teucrium section.

Extensive studies have been carried out on the phytochemical and pharmacological activities of the Teucrium species. In the legendary history of Cyprus, it is narrated that the medicinal properties

\footnotetext{
* Corresponding author: E-Mail: ihsan.calis@neu.edu.tr; Phone:+90 392-223 6464/5122
} 
of Teucrium species was put in use for the first time by the founder and king of the city of Salamis in Cyprus - whose name Teucer is hence associated with the naming of the species as Teucer, Teucru Teucros or Teucris [4]. It is known that the representatives of the genus Teucrium have been used for more than 2000 years as medicinal herbs. The ethnopharmacological claims for Teucrium species include the use of decoctions, or infusions as stimulants, tonics, diaphoretics, diuretics; and, for treatments of stomach pain, asthma, amenorrhea, leucorrhoea, chronic bronchitis; and, for gout in traditional medicine. They have also been used as antispasmolytic, hypoglycemic agents and for CNS depressant activities [5]. Teucrium polium is documented to be used for the curing of pathophysiological maladies such as diabetes, gastrointestinal disorders, rheumatism, inflammations. Besides, the same species is also discovered to be useful in diuretic, antipyretic, tonic, diaphoretic, analgesic and antihyperlipidemic activities [6-8].

The Teucrium species contain number of compound classes, which especially include phenylethanoid (=phenylpropanoid) glycosides, iridoid glycosides and neo-clerodane diterpenoids. In 1985, poluimoside - a phenylpropanoid (=phenylethanoid) glycoside - was isolated from Teucrium belion by Andary and friends [9]. In 1988, Gross and friends reported teucrioside - another phenylpropanoid glycoside - isolated from Teucrium chamaedrys [10]. Teucrioside is the first Llyxose containing phenylpropanoid glycoside found in nature. Also, in 1988, Andary and friends further made a chemotaxonomic study on the species, this time of $T$. polium examining the caffeic acid esters. Furthermore, several studies have demonstrated the wide range of biological and pharmacological activities of phenylethanoid glycosides, which are the main phenolic components, in Teucrium species [11].

The genus Teucrium is also one of the richest sources of clerodane-type diterpenoids [5]. Flavonoids and aromatic compounds, although furan containing neo-clerodane diterpenoids, have also been found in the genus [12]. Diterpenoids isolated from the aerial parts of Teucrium are those with a neoclerodane skeleton. More than 220 diterpenes have been described, all differing in the functional groups on the neoclerodane, or (on) the 19-nor-neoclerodane skeleton [13]. Neo-clerodane diterpenoids are accepted to be chemotaxonomic markers of the Teucrium species, which are known to be the most abundant natural source for these compounds. Teucrin A and teuchamaedryn A, classified as neo-clerodane diterpenoids, are natural toxic compounds. Their hepatoxicity is publicly confirmed after a 1992 dated incident, when out of 27 hepatoxicity cases in total - one resulting in death - the French Health Department forbid the sales of medicinal preparations containing Teucrium chamaedrys.

Since 1996, the Italian Ministry of Health considers its flowering tops used in teas as poison, as well as all the preparations obtained from T. chamaedrys [12]. The species of the genus Teucrium are very rich in phenolic compounds with very strong biological activity [14].

The aim of this study is to search secondary metabolites of Teucrium creticum L. T. creticum (Lat. "of Crete") is found in Eastern Mediterranean region from Turkey to Palestine [3]. This study resulted in the isolation and structure elucidation of two iridoids that are 8-O-acetylharpagide (1) and teuhircoside (2); two phenylethanoid glycosides, verbascoside (= acteoside) (3) and lavandulifolioside (4), and four neoclerodane-type diterpenoids; teucrin H3 (= 19-acetylgnaphalin) (5), teucjaponin B (6), teucretol (7) and diacetylteumassilin (8) (Figure 1).

\section{Materials and Methods}

\subsection{Plant Material}

Teucrium creticum L. was collected from south hillside of St. Hilarion, Cyprus in 25 May 2018 and identified by Prof. Dr. İhsan ÇALIŞ (Department of Pharmacognosy, Faculty of Pharmacy, Near East University, Nicosia, Cyprus), Azmi Hanoğlu, Duygu Yiğit Hanoğlu. A voucher specimen (NEUN 1675) has been deposited in the NEUN Herbarium of the Near East University.

\subsection{General Experimental Procedures}

Classical column chromatography and a gradient Medium Pressure Liquid Chromatography (Büchi MPLC equipped by Pump Modules C-601 \& C-605 with a pump Controller C-610 and pump 
manager C-605) and a Büchi Fraction Collector C-615 were used for the isolation process. Silica gel (0.063-200 mu, Merck), LiChroprep C-18 (0.063-200 mm, Merck) and Sephadex LH-20 were used as stationary phases throughout chromatographical studies. Silica gel alumina plates (Silica Gel 60 $\mathrm{F}_{254}$, Merck) were used for Thin Layer Chromatography. Melting points were determined using an Electrothermal IA9200 Digital Programmable Melting Point Apparatus (Cole Parmer). Optical rotations were measured on a Schmidt+Haensch Polartronic MHZ-8 polarimeter. UV Spectra were recorded on a T70 UV-VIS Spectrometer (PG Instruments Ltd.). For 1D and 2H NMR experiments were performed using Varian and Brucker DRX 500 spectrometers $\left({ }^{1} \mathrm{H}-\mathrm{NMR} ; 400\right.$ and $500 \mathrm{MHz} ;{ }^{13} \mathrm{C}$ NMR: 100 and $150 \mathrm{MHz}$, resp.) using the XWIN NMR software package for the data acquisition and processing. Negative- and positive-mode HRMS were recorded on a Finnigan TSQ 7000 and HRMass Spectrometer and a UPLC-Quadrupole Orbitrap instrument. For lyophlization a CHRIST Alpha 1-4 LD Plus was used. Throughout the study, Büchi R-210 and Heidolph 4001 rotary evaporators were used.

\subsection{Extraction}

The air-dried and powdered aerial parts of the plant material (100 g) was extracted by maceration procedure using $80 \%$ ethyl alcohol $(1000 \mathrm{~mL})$ for 48 hours. After maceration, the extract was filtered with vacuum by using Buchner funnel. Solvent was removed from the extract by rotary evaporator under reduced pressure at $50{ }^{\circ} \mathrm{C}$. During the concentration procedure, precipitated lipophilic compounds (chlorophil etc.) were removed by filtration. Water soluble part of the concentrated extract was fractionated by VLC.

\subsubsection{Fractionation and Isolation Studies}

Concentrated extract in water $(50 \mathrm{~mL})$ was subjected to a RP-VLC (50g LiChroprep RP-18) then fractionated by gradient elution using $\mathrm{H}_{2} \mathrm{O}-\mathrm{MeOH}$ mixtures with increasing amount of $\mathrm{MeOH}$ in $\mathrm{H}_{2} \mathrm{O}$ (Water: Methanol 100:0 $\rightarrow$ 0:100). According to the TLC profile of the fractions, they were combined into six fractions; frs. 2 and 3 (Fr. A, 5.7 g), fr. 4 (Fr. B, $323 \mathrm{mg}$ ), mixture of frs. 5, 6 and 7 (Fr. C, $975 \mathrm{mg}$ ), mixture of frs. 8 and 9 (Fr. D, 2.218 g), fr. 10 (Fr. E, $1.391 \mathrm{~g}$ ) and fr. 11 (Fr. F, 153 $\mathrm{mg})$.

\subsubsection{Isolation of iridoids, 1 and $\mathbf{2}$}

$4.8 \mathrm{~g}$ of fraction A $(5.7 \mathrm{~g})$ rich in sugars was coarsely fractionated over a short silica gel column $(50 \mathrm{~g})$ using eluent systems firstly DCM $(100 \mathrm{~mL})$ and a mixture of DCM-MeOH $(9: 1,100$ $\mathrm{mL} ; 8: 2,100 \mathrm{~mL} ; 7: 3,200 \mathrm{~mL}$ ) and finally with $\mathrm{DCM}-\mathrm{MeOH}-\mathrm{H}_{2} \mathrm{O}$ with an increasing polarity (80:20:2, 70:30:3 and 60:40:4; each $100 \mathrm{~mL}$ ) (fraction volume: $50 \mathrm{~mL}$ ). Fractions $7-12(750 \mathrm{mg}$ ) were rich in 1 and $\mathbf{2}$ which was further applied to RP-MPLC (Stationary phase: LiChroprep C-18; Column dimensions: $25 \mathrm{~mm} \times 250 \mathrm{~mm}$; Fraction volume: $15 \mathrm{~mL})$ using first $\mathrm{H}_{2} \mathrm{O}(100 \mathrm{~mL})$ and $\mathrm{H}_{2} \mathrm{O}$ $\mathrm{MeOH}$ mixture (gradient elution: $1-30 \% \mathrm{MeOH}$ in $\mathrm{H}_{2} \mathrm{O} ; 1200 \mathrm{~mL}$ ) and finally $\mathrm{MeOH}(200 \mathrm{~mL})$ as eluents. Fractions $37-52$ yielded $\mathbf{2}(150 \mathrm{mg})$, while fractions $70-86$ yielded $\mathbf{1}(136 \mathrm{mg})$. Fraction B (323 mg) was also rich in 1 which was further applied to a silica gel column (30 g) using a solvent system DCM-MeOH- $\mathrm{H}_{2} \mathrm{O}$ with an increasing polarity (90:10:1, $200 \mathrm{~mL} ; 85.15 .1,100 \mathrm{~mL} ; 80: 20: 2$, $100 \mathrm{~mL}$ and $70: 30: 3,100 \mathrm{~mL})$ to yield $\mathbf{1}(132 \mathrm{mg})$.

\subsubsection{Isolation of phenylethanoid glycosides, $\mathbf{3}$ and $\mathbf{4}$}

$2.13 \mathrm{~g}$ of fraction 8-9 (D) was subjected to a silica gel chromatography (130 g) with DCM$\mathrm{MeOH}-\mathrm{H}_{2} \mathrm{O}$ mixtures with an increasing polarity $(80: 20: 1 \rightarrow 60: 40: 6)$ to afford 52 fractions. According to the TLC, fractions containing similar compounds were combined into 14 fractions, D1-D14; D1 (65 mg), D2 (196 mg), D3 (236 mg), D4 (205 mg), D5 (275 mg), D6 (224 mg), D7 (53.7 mg), D8 (182 mg), D9 (54 mg), D10 (67 mg), D11 (83 mg), D12 (57 mg), D13 (23 mg), D14 (13 mg). Fr. D3 (236 $\mathrm{mg}$ ) was rich in $\mathbf{3}$ which was further applied to gel chromatography on a lipophilic Sephadex LH-20 
column $(25 \mathrm{~cm} \times 3 \mathrm{~cm})$ and using $\mathrm{MeOH}-\mathrm{H}_{2} \mathrm{O}$ mixture (1:1) to yield $3(22 \mathrm{mg})$. D7 afforded 4 (53.7 $\mathrm{mg})$. Additionally, Frs. D6 (224 mg), and D8 (182 mg) were also rich in 4.

\subsubsection{Isolation of neoclerodane-type diterpenoids, $\mathbf{5}-\mathbf{8}$}

Fractions E (Fr.10, $1.391 \mathrm{~g}$ ) and F (Fr.11, $153 \mathrm{mg}$ ) were rich in lipophilic compounds which was further subjected to silica gel column $(60 \mathrm{~g})$ using a mixture of DCM-Aceton. An increasing amount of acetone in DCM in every $100 \mathrm{~mL}$ of the solvent mixture was applied [(stepwise gradient elution; 90:10 $(400 \mathrm{~mL}), 85: 15(200 \mathrm{~mL}), 80: 20(300 \mathrm{~mL})]$. 76 Fractions were collected which were combined into 10 groups according to their TLC profiles (E1 - E10). Frs. E2 and E6 gave compounds 5 and 6, (3 mg and $11 \mathrm{mg}$, resp.). Fr. E10 (74 mg) was further applied to a Sephadex LH-20 column $(\emptyset 2 \mathrm{~cm}, \mathrm{~h}=30 \mathrm{~cm})$ using a mixture of Cyclohexane-Aceton-MeOH (7:2:1) to give $7(25 \mathrm{mg})$ which was the major compound among the neo-clerodane type diterpenoids. Fr. F (fr. 11, $153 \mathrm{mg}$ ) was firstly applied to a silica gel column using DCM-MeOH- $\mathrm{H}_{2} \mathrm{O}$ as mobile phase with increasing polarity (95:5:0.5 $\rightarrow 80: 20: 1)$. Fractions rich in compound 8 were further subjected to a Sephadex LH-20 column $(\varnothing 2 \mathrm{~cm}, \mathrm{~h}=30 \mathrm{~cm})$ using a mixture of Cyclohexane-Acetone-MeOH $(7: 2: 1)$ to give 8 (25 $\mathrm{mg})$.
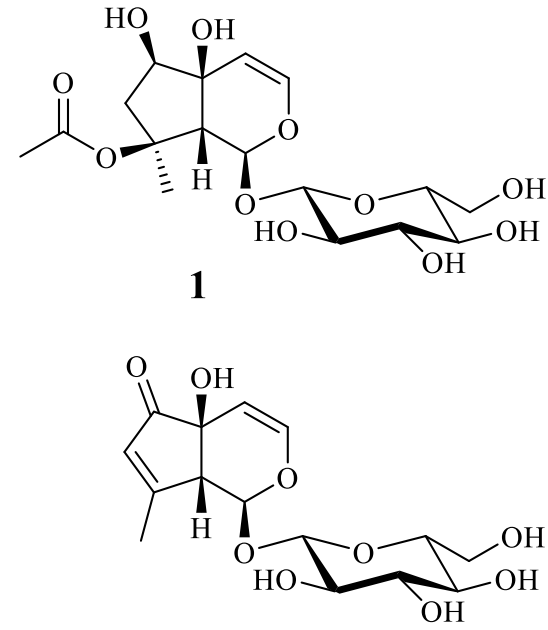

2

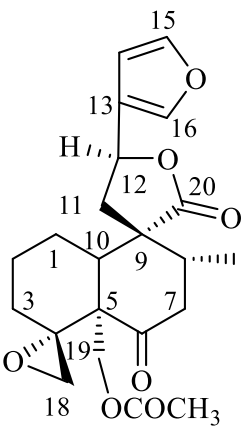

5

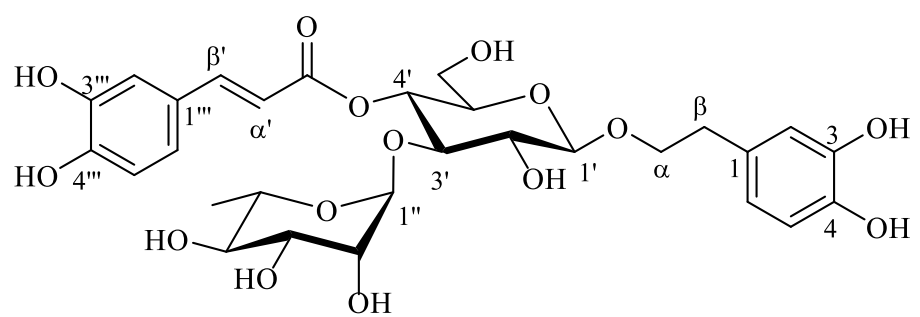

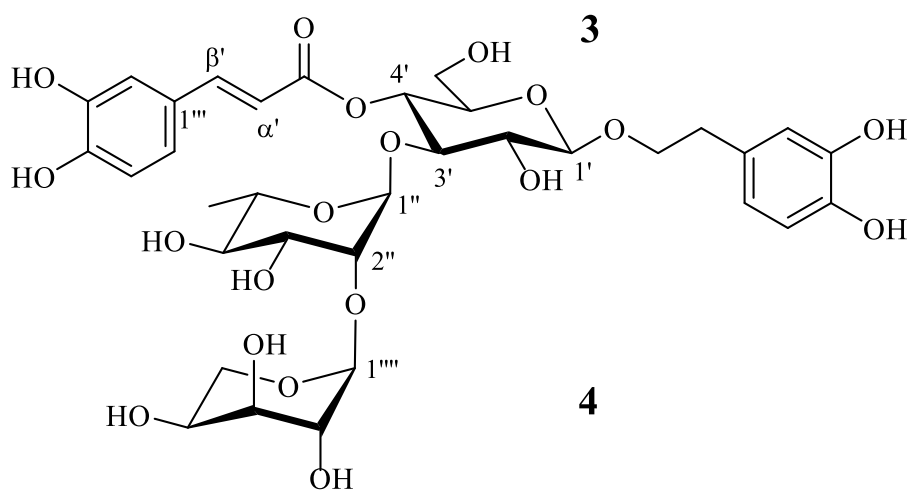

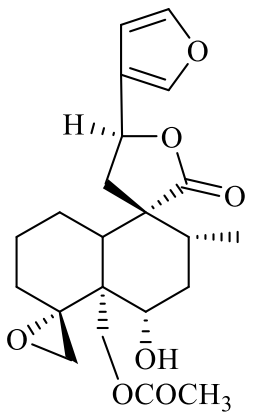

6

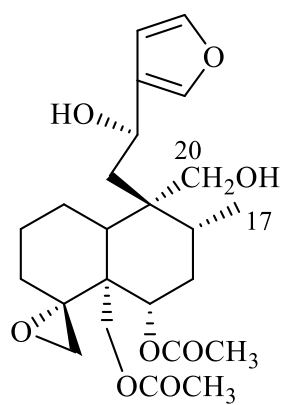

7<smiles>CO[C@H]1C[C@H](C)[C@]2(C)C(CCC[C@@]23CO3)[C@@]1(C)CCc1ccoc1</smiles>

8

Figure 1. The structures of the compounds $\mathbf{1}-\mathbf{8}$ isolated from Teucrium creticum $\mathrm{L}$. 
8-O-Acetylharpagide (1): $[\alpha]_{\mathrm{D}}{ }^{20}-142.7^{\circ}(\mathrm{c} 0.22, \mathrm{MeOH})$; UV (MeOH) $\lambda_{\max } 211 \mathrm{~nm} ;{ }^{1} \mathrm{H}$ and ${ }^{13} \mathrm{C} \mathrm{NMR}$ $\left(\mathrm{CD}_{3} \mathrm{OD}\right)$ data, see Table 1.

Teuhircoside (2): $[\alpha]_{\mathrm{D}}{ }^{20}-218.8^{\circ}$ (c 0.16, MeOH); UV (MeOH) $\lambda_{\max } 228$ and $210(\mathrm{sh}) \mathrm{nm} ;{ }^{1} \mathrm{H}$ and ${ }^{13} \mathrm{C}$ NMR $\left(\mathrm{CD}_{3} \mathrm{OD}\right)$ data, see Table 1.

Verbascoside ( $=$ acteoside $)(3):{ }^{1} \mathrm{H}$ and ${ }^{13} \mathrm{C}$ NMR $\left(\mathrm{CD}_{3} \mathrm{OD}\right)$ data, see Table 2.

Lavandulifolioside (4): ${ }^{1} \mathrm{H}$ and ${ }^{13} \mathrm{C}$ NMR $\left(\mathrm{CD}_{3} \mathrm{OD}\right)$ data, see Table 2.

Teucrin H3 = 19-acetylgnaphalin (5): $[\alpha]_{\mathrm{D}}{ }^{20}+59.1^{\circ}\left(\mathrm{c} 0.115, \mathrm{CHCl}_{3}\right) ;{ }^{1} \mathrm{H}$ and ${ }^{13} \mathrm{C} \mathrm{NMR}\left(\mathrm{CDCl}_{3}\right)$ data, see Tables 3 and 4; (+)-HRMS m/z $425.1564(100 \%)[\mathrm{M}+\mathrm{H}]^{+}, 827.3237[2 \mathrm{M}+\mathrm{H}]^{+}$(calcd. for $\mathrm{C}_{22} \mathrm{H}_{26} \mathrm{O}_{7} \mathrm{Na}$ : 425.1576; Mol. wt. 402,1679).

Teucjaponin B (6): $[\alpha]_{\mathrm{D}}{ }^{20}+47.6^{\circ}\left(\mathrm{c} 0.084, \mathrm{CHCl}_{3}\right) ;{ }^{1} \mathrm{H}$ and ${ }^{13} \mathrm{C}$ NMR $\left(\mathrm{CD}_{3} \mathrm{OD}\right)$ data, see Tables 3 and 4; (+)-HRMS m/z 405.1900 [M+H] ${ }^{+}, 427.1719(87 \%)[\mathrm{M}+\mathrm{Na}]^{+}, 831.3549[2 \mathrm{M}+\mathrm{H}]^{+}$(calcd. for $\mathrm{C}_{22} \mathrm{H}_{28} \mathrm{O}_{7} \mathrm{Na}$ : 427.1733; Mol. wt. 404.1835).

Teucretol (7): $[\alpha]_{\mathrm{D}}{ }^{20}-12.7^{\circ}\left(\mathrm{c} 0.157, \mathrm{CHCl}_{3}\right) ;{ }^{1} \mathrm{H}$ and ${ }^{13} \mathrm{C}$ NMR $\left(\mathrm{CD}_{3} \mathrm{OD}\right)$ data, see Tables 3 and 4; (+)HRMS m/z $451.2321(45 \%)[\mathrm{M}+\mathrm{H}]^{+} 473.2136(100 \%)[\mathrm{M}+\mathrm{Na}]^{+}$(calcd. for $\mathrm{C}_{24} \mathrm{H}_{34} \mathrm{O}_{8} \mathrm{Na}: 473.2151$; Mol. wt. 450.2254).

Diacetylteumassulin (8): $[\alpha]_{\mathrm{D}}{ }^{20}-9.2^{\circ}\left(\mathrm{c} 0.35, \mathrm{CHCl}_{3}\right) ;{ }^{1} \mathrm{H}$ and ${ }^{13} \mathrm{C} \mathrm{NMR}\left(\mathrm{CD}_{3} \mathrm{OD}\right)$ data, see Tables 3 and 4; (+)-HRMS m/z $435.2373(30 \%)[\mathrm{M}+\mathrm{H}]^{+}$and $457.2191(100 \%)[\mathrm{M}+\mathrm{Na}]^{+}$(calcd. for $\mathrm{C}_{24} \mathrm{H}_{34} \mathrm{O}_{7} \mathrm{Na}$ : 457.2202; Mol. wt. 434.2305).

\section{Results and Discussion}

\subsection{Structure Elucidation}

Compound 1 was obtained as a colorless compound, $[\alpha]_{\mathrm{D}}{ }^{20}-142.7^{\circ}(\mathrm{c}=0.22, \mathrm{MeOH})$. The UV $\left(\lambda_{\max } 211 \mathrm{~nm}, \mathrm{MeOH}\right)$ and ${ }^{1} \mathrm{H}-\mathrm{NMR}\left(\delta 6.38 \mathrm{~d}, J_{3,4}=6.4 \mathrm{~Hz}, \mathrm{H}-3 ; 4.91 \mathrm{dd}, J_{4,3}=6.4\right.$ and $J_{4.9}=1.6 \mathrm{~Hz}$, $\mathrm{H}-4)$ spectra of 1 indicated a non-conjugated iridoid enol-ether system (Table 1) indicating an aucubin-type iridoid structure. ${ }^{13} \mathrm{C}-\mathrm{NMR}$ spectrum exhibited 17 carbon resonances; six of them were attributed to a $\beta$-D-glucopyranosyl unit while two of them were ascribed to the methyl and carbonyl carbons of an acetoxyl group. The remaining carbon resonances indicated that $\mathbf{1}$ has an iridoid (cyclopentanpyrane ring system) with nine carbon atoms. The complete assignments of all proton and carbon resonances were based on 2D-NMR (COSY, HSQC, HMBC and NOESY) experiments. The proton signals arising from an $\mathrm{ABX}$ system at $\delta 2.18$ and 1.94 (each dd, $J_{\mathrm{AB}} 15.2 \mathrm{~Hz}, J_{\mathrm{AX}}=4.5 \mathrm{~Hz}, J_{\mathrm{BX}}$ $=1.2 \mathrm{~Hz}, \mathrm{H}_{2}-7 ; \mathrm{AB}$ of $\left.\mathrm{ABX}\right)$ and $3.71(\mathrm{dd}, \mathrm{J}=4.5$ and $1.2 \mathrm{~Hz}, \mathrm{H}-6 ; \mathrm{X}$ of $\mathrm{ABX})$ and the corresponding carbon resonances ( $\delta 46.0$ and 78.2) were assigned to $\mathrm{H}_{2}-7 / \mathrm{C}-7$ and $\mathrm{H}-8 / \mathrm{C}-8$, respectively. This statement was supported with the presence of two oxygen-bearing quaternary carbon resonances on both ends of this spin system ascertained as C-5 $(\delta 73.3)$ and C-8 $(\delta$ 88.6). The remaining proton signals at $\delta 6.08\left(1 \mathrm{H}, \mathrm{d}, J_{1,9}=1.2 \mathrm{~Hz}\right) 2.85\left(1 \mathrm{H}, \mathrm{dd}, J_{9,1}=1.2 \mathrm{~Hz}\right.$ and $\left.J_{9,4}=1.6 \mathrm{~Hz}\right), 1.45(3 \mathrm{H}, \mathrm{s})$ were determined as $\mathrm{H}-1, \mathrm{H}-9$ and $\mathrm{H}_{3}-10$, respectively. The prominent $\mathrm{HMBC}$ correlations from $\mathrm{C}-1$ to $\mathrm{H}-1$ ', H-3 and H-9, from C-5 to H-1, H-3, H-9 and H-6, from C-9 to H-4, H-6 and $\mathrm{H}_{2}-7$, and from C-8 to H$1, \mathrm{H}-9, \mathrm{H}_{2}-7$ and $\mathrm{H}_{3}-10$ supported the proposed structure for 1 . Moreover, the NOE between $\mathrm{H}-1 / \mathrm{H}_{3}-$ 10 and $\mathrm{H}-7 / \mathrm{H}_{3}-10$ indicated that these protons are on the same side $(\alpha)$ of the cyclopentanepyrane system confirming relative configuration. Additional NOE between $\mathrm{H}-1 / \mathrm{H}-1^{\prime}$ supported the glycosidation site. The spectral data established the structure of $\mathbf{1}$ to be 8-O-acetylharpagide [15].

Compound 2 was obtained as a colorless compound, $[\alpha]_{D^{20}}-218.8^{\circ}(\mathrm{c}=0.16, \mathrm{MeOH})$. The UV $\left(\lambda_{\max } 228 \mathrm{~nm}\right.$ and $\left.210 \mathrm{sh}\right)$ and the ${ }^{1} \mathrm{H}-\mathrm{NMR}$ spectrum of $2\left[\mathrm{CD}_{3} \mathrm{OD} ; \delta 6.29\left(\mathrm{~d}, J_{3,4}=6.4 \mathrm{~Hz}, \mathrm{H}-3\right), 4.87\right.$ (dd, $\left.J_{4,3}=6.4, J_{4,9}=1.6 \mathrm{~Hz}, \mathrm{H}-4\right)$ ], and 5.94 (q, H-7) indicated a non-conjugated iridoid enol-ether system and a conjugated enone system in a cyclopentane ring. The complete assignment of the 'H- 
NMR spectrum is based on a homonuclear COSY experiment (Table 1). The starting point for the analysis of the iridoid protons is the " $d$ " at $6.29 \mathrm{ppm}(\mathrm{H}-3)$. It shows a correlation peak only with the " $d d$ " at 4.87 ppm which confirms its assignment to H-4 which was further coupled to the " $m$ " at 3.22 ppm (H-9) and " $b r s$ " at $2.23 \mathrm{ppm}(3 \mathrm{H})$, assigned to $\mathrm{H}_{3}-10$. Moreover, $\mathrm{H}-9$ shows correlations to both $\mathrm{H}_{3}-10$ and to the " $d$ " at $6.0 \mathrm{ppm}\left(J_{1,9}=1.6 \mathrm{~Hz}, \mathrm{H}-1\right)$. The olefinic proton signal observed at $\delta 5.94(\mathrm{q})$ showed correlations to $\mathrm{H}_{3}-10$ and $\mathrm{H}-9$, was therefore assigned to $\mathrm{H}-7$. This significant coupling pattern suggests a 7-ene-6-one structure, and the experimental results are also in good agreement with the reported data for allobetonicoside, teuhircoside and teucardoside with a similar iridoid skeleton [16$18]$.

The ${ }^{13} \mathrm{C}-\mathrm{NMR}$ spectrum of 2 confirmed this assumption as the chemical shifts of the relevant iridoid C-atoms are similar to those of teuhircoside except small differences based on the solvent effect [16]. The signals observed at $\delta 174.7$ and 206.8 were assigned to C-8 and C-6, respectively. The former showed the ${ }^{13} \mathrm{C},{ }^{1} \mathrm{H}$-heteronuclear long-range correlations to $\mathrm{H}-1, \mathrm{H}-9$ and $\mathrm{H}_{3}-10$ while the latter showed the correlations to $\mathrm{H}-4, \mathrm{H}-7$ and $\mathrm{H}_{3}-10$.

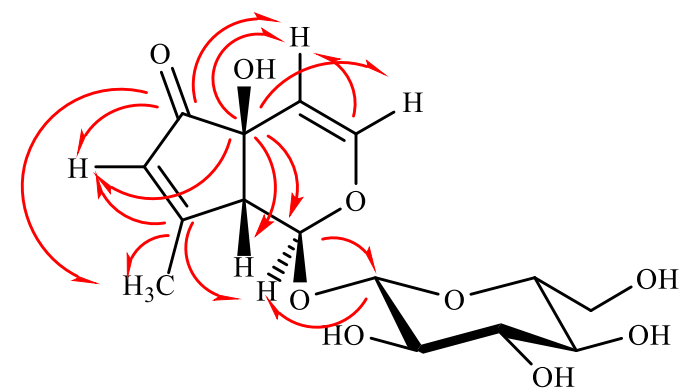

Figure 2. The significant ${ }^{13} \mathrm{C},{ }^{1} \mathrm{H}$-long-range Heteronuclear Correlations for $\mathbf{2}$.

Table 1. ${ }^{13} \mathrm{C}$ ve ${ }^{1} \mathrm{H}$ NMR Data of 8-O-acetyl-harpagide (1) and Teuhircoside $(2)\left(\mathrm{CD}_{3} \mathrm{OD},{ }^{* 13} \mathrm{C}\right.$ : 100 $\left.\mathrm{MHz} ;{ }^{1} \mathrm{H}: 400 \mathrm{MHz}\right)$

\begin{tabular}{lllllll}
\hline C/H Atom & \multicolumn{2}{l}{ 8- $O$-acetyl-harpagide $(\mathbf{1})$} & \multicolumn{2}{l}{ Teuhircoside (2) } \\
\hline & $\mathrm{DEPT}$ & $\delta_{\mathrm{C}} \mathrm{ppm}$ & $\delta_{\mathrm{H}} \mathrm{ppm}, J(\mathrm{~Hz})$ & $\mathrm{DEPT}$ & $\delta_{\mathrm{C}} \mathrm{ppm}$ & $\delta_{\mathrm{H}} \mathrm{ppm}, J(\mathrm{~Hz})$ \\
\hline 1 & $\mathrm{CH}$ & 94.5 & $6.08 \mathrm{~d}(1.2)$ & $\mathrm{C}$ & 91.7 & $6.0 \mathrm{~d}(1.6)$ \\
3 & $\mathrm{CH}$ & 143.9 & $6.38 \mathrm{~d}(6.4)$ & $\mathrm{CH}$ & 142.6 & $6.29 \mathrm{~d}(6.4)$ \\
4 & $\mathrm{CH}$ & 106.9 & $4.91 \mathrm{dd}(6.4,1.6)$ & $\mathrm{CH}$ & 105.1 & $4.87 \mathrm{dd}(6.4,1.6)$ \\
5 & $\mathrm{C}$ & 73.3 & - & $\mathrm{CH}$ & 72.9 & - \\
6 & $\mathrm{CH}$ & 78.2 & $3.71 \mathrm{dd}(1.2,4.5)$ & $\mathrm{C}$ & 206.8 & - \\
7 & $\mathrm{CH}_{2}$ & 46.0 & $2.18 \mathrm{dd}(15.2,1.2)$ & $\mathrm{CH}$ & 128.8 & 5.94 qui \\
& & & $1.94 \mathrm{dd}(15.2,4.5)$ & & & \\
8 & $\mathrm{C}$ & 88.6 & - & $\mathrm{C}$ & 174.7 & - \\
9 & $\mathrm{CH}$ & 55.4 & $2.85 \mathrm{br} \mathrm{s}$ & $\mathrm{CH}$ & 58.0 & $3.22 \dagger$ \\
10 & $\mathrm{CH}_{3}$ & 22.5 & $1.45 \mathrm{~s}$ & $\mathrm{CH}_{3}$ & 17.9 & $2.23 \mathrm{br} \mathrm{s}$
\end{tabular}

\begin{tabular}{lllllll}
$\mathrm{COCH}_{3}$ & $\mathrm{C}$ & 173.3 & - & & & \\
$\mathrm{COCH}_{3}$ & $\mathrm{CH}_{3}$ & 22.2 & $2.01 \mathrm{~s}$ & & & \\
Glucose & & & & & \\
$1^{\prime}$ & $\mathrm{CH}$ & 99.9 & $4.58 \mathrm{~d}(8.0)$ & $\mathrm{CH}$ & 99.1 & $4.55 \mathrm{~d}(8.0)$ \\
$2^{\prime}$ & $\mathrm{CH}$ & 74.6 & $3.19 \mathrm{dd}(8.0,9.2)$ & $\mathrm{CH}$ & 75.1 & $3.21 \mathrm{dd}(8.0,9.2)$ \\
$3^{\prime}$ & $\mathrm{CH}$ & 77.5 & $3.38 \mathrm{t}(9.2)$ & $\mathrm{CH}$ & 77.5 & $3.38 \mathrm{t}(9.0)$ \\
$4^{\prime}$ & $\mathrm{CH}$ & 71.7 & $3.43 \mathrm{t}(9.0)$ & $\mathrm{CH}$ & 71.7 & $3.27 \mathrm{t}(9.0)$ \\
$5^{\prime}$ & $\mathrm{CH}$ & 77.6 & $3.64-3.50 \dagger$ & $\mathrm{CH}$ & 78.5 & $3.30 \dagger$ \\
$6^{\prime}$ & $\mathrm{CH}_{2}$ & 62.8 & $3.88 \mathrm{dd}(12.4,1.6)$ & $\mathrm{CH}_{2}$ & 62.8 & $3.92 \mathrm{dd}(12.0,2.2)$ \\
& & & $3.68 \mathrm{dd}(12.4,5.6)$ & & & $3.66 \mathrm{dd}(12.0,6.0$ \\
\hline
\end{tabular}

\# The assignments are based on 2D NMR experiments (COSY, HSQC and HMBC)

$\dagger$ The signal pattern is unclear due to overlapping. 
These observations confirmed the suggested iridoid skeleton exhibiting a 7-ene-6-one structure for 2. The second spin system observed in the COSY experiment and corresponding carbon resonances assigned by the help of HSQC experiment allowed the presence of a $\beta$-D-glucopyranose unit. The glycosidation site was determined by the help of HMBC (Figure 2), which showed the ${ }^{13} \mathrm{C},{ }^{1} \mathrm{H}$-heteronuclear long-range correlation from $\mathrm{C}-1(\delta$ 91.7) to the anomeric proton of D-glucose $(\delta$ $\left.4.55, \mathrm{~d}, \mathrm{~J}=8.0 \mathrm{~Hz}, \mathrm{H}-1^{\prime}\right)$ and the vice versa correlation from the anomeric carbon of the glucose $(\delta$ $99.1, \mathrm{C}-1$ ') to $\mathrm{H}-1$ of the iridoid moiety $(\delta 6.0, \mathrm{~d}, J=1.6 \mathrm{~Hz})$. Furthermore, $\mathrm{C}-1$ showed the long-range correlations to H-3, H-7 and H-9. Based on these observations, compound 2 was identified as teuhircoside [17].

Table 2. ${ }^{13} \mathrm{C}$ ve ${ }^{1} \mathrm{H}$ NMR Data of Verbascoside (3) and Lavandulifolioside (4) ${ }^{*}$

\begin{tabular}{|c|c|c|c|c|c|}
\hline \multirow[b]{2}{*}{ C/H Atom } & & \multicolumn{2}{|r|}{3} & \multicolumn{2}{|r|}{4} \\
\hline & & $\delta_{\mathrm{C}} \mathrm{ppm}$ & $\delta_{\mathrm{H}} \mathrm{ppm}, J(\mathrm{~Hz})$ & $\delta_{\mathrm{C}} \mathrm{ppm}$ & $\delta_{\mathrm{H}} \mathrm{ppm}, J(\mathrm{~Hz})$ \\
\hline Aglycone 1 & $\mathrm{C}$ & 131.5 & & 131.4 & \\
\hline 2 & $\mathrm{CH}$ & 117.1 & $6.68 \mathrm{~d}(2.0)$ & 117.1 & $6.69 \mathrm{~d}(2.0)$ \\
\hline 3 & $\mathrm{C}$ & 146.1 & & 146.1 & \\
\hline 4 & $\mathrm{C}$ & 144.7 & & 144.7 & \\
\hline 5 & $\mathrm{CH}$ & 116.3 & $6.55 \mathrm{dd}(2.0,8.0)$ & 116.3 & $6.56 \mathrm{dd}(2.0,8.0)$ \\
\hline 6 & $\mathrm{CH}$ & 121.2 & $6.66 \mathrm{~d}(8.0)$ & 121.3 & $6.67 \mathrm{~d}(8.0)$ \\
\hline$\alpha$ & $\mathrm{CH}_{2}$ & 72.3 & $4.04 \mathrm{~m}, 3.71 \mathrm{~m}$ & 72.3 & $4.05 \mathrm{~m}, 3.70 \mathrm{~m}$ \\
\hline$\beta$ & $\mathrm{CH}_{2}$ & 36.6 & 2.79 brt (7.4) & 36.6 & $2.79 \mathrm{t}(7.4)$ \\
\hline Glucose 1' & $\mathrm{CH}$ & 104.2 & $4.37 \mathrm{~d}(8.0)$ & 104.2 & $4.37 \mathrm{~d}(8.0)$ \\
\hline $2^{\prime}$ & $\mathrm{CH}$ & 76.2 & $3.38 \mathrm{dd}(8.0,9.2)$ & 76.0 & $3.38 \mathrm{dd}(8.0,9.2)$ \\
\hline $3^{\prime}$ & $\mathrm{CH}$ & 81.6 & $3.81 \mathrm{t}(9.2)$ & 82.4 & $3.75-3.80^{\dagger}$ \\
\hline $4^{\prime}$ & $\mathrm{CH}$ & 70.4 & $4.90 \mathrm{t}(9.0)$ & 70.4 & $4.92^{\dagger}$ \\
\hline $5^{\prime}$ & $\mathrm{CH}$ & 76.0 & $3.64-3.50^{\dagger}$ & 76.0 & $3.50-3.60^{\dagger}$ \\
\hline $6^{\prime}$ & $\mathrm{CH}_{2}$ & 62.4 & $3.64-3.50^{\dagger}$ & 62.3 & $3.60-3.66^{\dagger}$ \\
\hline Rhamnose 1" & $\mathrm{CH}$ & 103.0 & $5.18 \mathrm{~d}(1.6)$ & 102.0 & $5.49 \mathrm{~d}(1.6)$ \\
\hline $2 "$ & $\mathrm{CH}$ & 72.3 & $3.91 \mathrm{dd}(1.6,3.2)$ & 82.9 & $3.94 \mathrm{dd}(1.6,3.2)$ \\
\hline 3" & $\mathrm{CH}$ & 72.1 & $3.56 \mathrm{dd}(3.2,9.6)$ & 72.3 & $3.49 \mathrm{dd}(3.2,9.6)$ \\
\hline $4 "$ & $\mathrm{CH}$ & 73.8 & $3.28 \mathrm{t}(9.6)$ & 74.2 & $3.27 \mathrm{t}(9.6)$ \\
\hline $5 "$ & $\mathrm{CH}$ & 70.6 & $3.60 \mathrm{~m}$ & 70.6 & $3.50-3.60^{\dagger}$ \\
\hline 6" & $\mathrm{CH}_{3}$ & 18.5 & $1.08 \mathrm{~d}(6.0)$ & 18.4 & $1.05 \mathrm{~d}(6.0)$ \\
\hline Arabinose 1"'" & $\mathrm{CH}$ & & & 107.5 & $4.30 \mathrm{~d}(7.0)$ \\
\hline $2^{\prime \prime \prime \prime}$ & $\mathrm{CH}$ & & & 72.8 & $3.60-3.66^{\dagger}$ \\
\hline $3^{\prime \prime \prime \prime}$ & $\mathrm{CH}$ & & & 74.4 & $3.48-3.56^{\dagger}$ \\
\hline $4 " ' 1$ & $\mathrm{CH}$ & & & 69.9 & $3.74-3.80^{\dagger}$ \\
\hline $5^{\prime \prime \prime \prime}$ & $\mathrm{CH}_{2}$ & & & 67.3 & $\begin{array}{l}3.85 \mathrm{dd}(12.8,2.8) \\
3.48-3.56^{\dagger}\end{array}$ \\
\hline Caffeoyl 1"' & $\mathrm{C}$ & 127.6 & & 127.6 & \\
\hline $2 " '$ & $\mathrm{CH}$ & 115.2 & $7.04 \mathrm{~d}(2.0)$ & 115.2 & $7.05 \mathrm{~d}(2.0)$ \\
\hline $3^{\prime \prime \prime}$ & $\mathrm{C}$ & 146.9 & & 146.8 & \\
\hline 4 "' & $\mathrm{C}$ & 149.9 & & 149.8 & \\
\hline $5^{\prime \prime \prime}$ & $\mathrm{CH}$ & 116.5 & $6.94 \mathrm{dd}(2.0,8.0)$ & 116.5 & $6.95 \mathrm{dd}(2.0,8.0)$ \\
\hline $6^{\prime \prime \prime}$ & $\mathrm{CH}$ & 123.2 & $6.76 \mathrm{~d}(8.0)$ & 123.2 & $6.77 \mathrm{~d}(8.0)$ \\
\hline$\alpha^{\prime}$ & $\mathrm{CH}$ & 114.7 & $6.27 \mathrm{~d}(15.6)$ & 114.6 & $6.27 \mathrm{~d}(15.6)$ \\
\hline$\beta^{\prime}$ & $\mathrm{CH}$ & 148.0 & $7.59 \mathrm{~d}(15.6)$ & 148.0 & $7.60 \mathrm{~d}(15.6)$ \\
\hline $\mathrm{C}=\mathrm{O}$ & $\mathrm{C}$ & 168.3 & & 168.3 & \\
\hline
\end{tabular}

$\left({ }^{*} \mathrm{CD}_{3} \mathrm{OD},{ }^{13} \mathrm{C}: 100 \mathrm{MHz} ;{ }^{1} \mathrm{H}: 400 \mathrm{MHz}\right)$.

${ }^{\dagger}$ Signal pattern unclear due to overlapping.

Compounds 3 and 4 were obtained as pale yellow, amorphous compounds. The ${ }^{1} \mathrm{H}$ NMR spectra of $\mathbf{3}$ and $\mathbf{4}$ (see Table 2) exhibited the protons of two aromatic rings as $\mathrm{ABX}$ systems which were characteristic for $(E)$-caffeic acid and 3,4-dihydroxyphenylethanol moieties $(\mathrm{H}-2, \mathrm{H}-5$ and $\mathrm{H}-6$ of 3,4dihydroxyphenetyl moiety and H-2"', H-5"' and H-6"' of. Additionally, two trans-olefinic protons as an 
AB system $\left(J_{\mathrm{AB}}=15.6 \mathrm{~Hz}, \mathrm{H}-\alpha^{\prime}\right.$ and $\left.\mathrm{H}-\beta^{\prime}\right)$, a benzylic $\beta$-methylene protons at $\delta 2.79(2 \mathrm{H}, \mathrm{br} \mathrm{t}, J=7.4$ $\mathrm{Hz}, \mathrm{H}_{2}-\beta$ ), and two nonequivalent hydroxymethylene protons at $\delta 4.04 / 4.05$ and $3.70 / 3.71$ (each $1 \mathrm{H}$, $\left.\mathrm{m}, \mathrm{H}_{2}-\alpha\right)$ of the side-chain of the aglycon moiety were observed as the common signals of $\mathbf{3}$ and $\mathbf{4}$. The ${ }^{13} \mathrm{C}$ NMR spectra of $\mathbf{3}$ and $\mathbf{4}$ were consistent for the presence of a caffeic acid, 3,4dihydroxyphenyl ethanol and di- and triglycosidic sugar moieties characteristic for the phenylethanoid glycosides except the number of anomeric proton signals. The ${ }^{1} \mathrm{H}-\mathrm{NMR}$ spectrum of $\mathbf{3}$ indicated a diglycosidic structure consisting of a hexose and methylpentose $=6$-deoxy-hexose $(\delta 4.37, \mathrm{~d}, J=8.0$ $\mathrm{Hz}, \mathrm{H}-1$ ' of $\beta$-D-glucose; $\delta 5.18, \mathrm{~d}, J=1.6 \mathrm{~Hz}, \mathrm{H}-1$ " of $\alpha$-L-rhamnose). The glycosidation shift observed in ${ }^{13} \mathrm{C}-\mathrm{NMR}$ experiment for $\mathrm{C}-3$ ' of glucose $(\delta 81.6)$ and the downfield shift observed for $\mathrm{H}$ 4' of glucose moiety $(\delta 4.90 \mathrm{t}, \mathrm{J}=9.0 \mathrm{~Hz})$ clearly supported the structure of compound $\mathbf{3}$ as verbascoside (= acteoside) [19]. The ${ }^{1} \mathrm{H}$ - and ${ }^{13} \mathrm{C}-\mathrm{NMR}$ spectra of $\mathbf{4}$ indicated a triglycosidic structure consisting of a hexose, a methylpentose and a pentose $(\delta 4.37, \mathrm{~d}, J=8.0 \mathrm{~Hz}, \mathrm{H}-1$ ' of $\beta$-D-glucose; $\delta$ $5.49, \mathrm{~d}, J=1.6 \mathrm{~Hz}, \mathrm{H}-1$ " of $\alpha$-L-rhamnose; $\delta 4.30, \mathrm{~d}, J=7.0 \mathrm{~Hz}, \mathrm{H}-1$ '"' of $\alpha$-L-arabinose) units. The corresponding carbon resonances of the arabinose unit indicated its terminal position. Additional glycosidation shift observed for C-2" of rhamnose unit $(\delta 82.9)$ which pointed out the glycosidation site of the third sugar, arabinose on the rhamnose unit to be $\mathrm{C}-2(\mathrm{OH})$. This suggestion was supported by the $+0.30 \mathrm{ppm}$ down-field shift of the anomeric proton resonance of $\alpha$-L-rhamnose unit $(\delta 5.49, \mathrm{~d}$, $J=1.6 \mathrm{~Hz}, \mathrm{H}-1 ")$ substituted at $\mathrm{C}-2 "(\mathrm{OH})$ in comparison to those of verbascoside $(\delta 5.18, \mathrm{H}-1 ")$. Based on the ${ }^{1} \mathrm{H}$ - and ${ }^{13} \mathrm{C}$-NMR data, the structure of $\mathbf{4}$ determined as lavandulifolioside which was firstly reported from Stachys lavandulifolia [20].

Compound 5 was obtained as a white amorphous compound. The positive ion HR-MS of $\mathbf{5}$ gave a quasimolecular ion $[\mathrm{M}+\mathrm{Na}]^{+}$peaks at $\mathrm{m} / \mathrm{z} 425,1564$ compatible with the molecular formula of $\mathrm{C}_{22} \mathrm{H}_{26} \mathrm{O}_{7} \mathrm{Na}$ ( $\mathrm{Mr}$ of 425,1576 ) and 10 degrees of unsaturation. This result indicated that the molecular weight of 5 is to be $402,1679\left(\mathrm{C}_{22} \mathrm{H}_{26} \mathrm{O}_{7}\right)$.

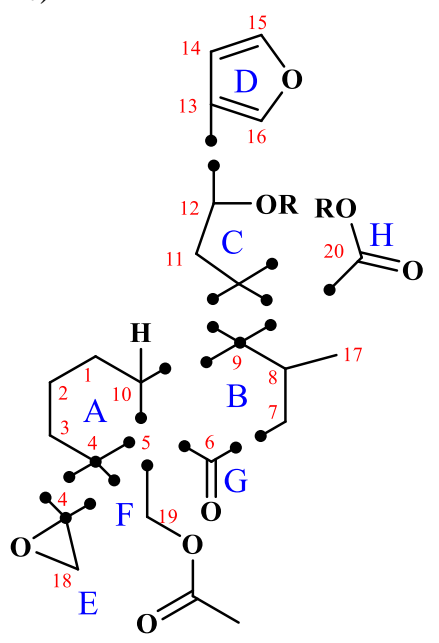

Figure 3. Molecular fragments of compound 5 deduced from 2D-NMR experiments

The ${ }^{13} \mathrm{C}$-NMR of $\mathbf{5}$ displayed the 22 carbon resonances due to a methyl, an acetoxy methyl, seven methylene (two oxygenated), six methine (one oxygenated and three olefinic), and seven quaternary (two oxygenated, one olefinic, and three carbonyl) carbon atoms (Table 4). The assignments of all proton signals were based on a COSY experiment (Table 3). After assigning of the proton signals, the corresponding carbon resonances were established via ${ }^{13} \mathrm{C}-{ }^{1} \mathrm{H}$ shift-correlated one-bond (HSQC) experiment. Thus, eight molecular fragments $(\mathrm{A}-\mathrm{H})$ were established (Figure 3 ). The ${ }^{1} \mathrm{H}-\mathrm{NMR}$ spectrum of $\mathbf{5}$ revealed the proton signals assigned to three methylene resonances belonging to the A ring $\left(\mathrm{H}_{2}-1, \mathrm{H}_{2}-2\right.$ and $\left.\mathrm{H}_{2}-3\right)$ which were observed in the same spin system. Additionally, a methine signal at $\delta 2.05(1 \mathrm{H}, \mathrm{dd}, \mathrm{J}=13.4$ and $3.7 \mathrm{~Hz}, \mathrm{H}-10)$ was found to be part of this spin network (fragment A). A secondary methyl resonance (Me-17) was observed in the same spin system with the proton at $\delta 1.94(1 \mathrm{H}, \mathrm{H}-8)$ and the methylene protons at $\delta 3.47(\mathrm{t}, J=13.5 \mathrm{~Hz}, \mathrm{H}-7 \mathrm{a})$ and 2.08 (dd, $J=13.5$ and $3.8 \mathrm{~Hz}, \mathrm{H}-7 \mathrm{~b}$ ) (fragment B). A proton signal at $\delta 5.39$ (t, $J=9.6 \mathrm{~Hz}, \mathrm{H}-12$ ) 
and two protons at $\delta 2.38\left(2 \mathrm{H}, \mathrm{dd}, J=8.5 \mathrm{~Hz}, \mathrm{H}_{2}-11\right)$ were observed as an ABX system. This molecular fragment (- $\mathrm{CH}_{2}$-CHX-O-) supported the presence of a $\gamma$-spirolactone moiety (fragment $\mathrm{C}$ ). Three protons at $\delta 6.31,7.36$ and 7.37 (each $1 \mathrm{H}$, br s, H-14, H-15, and H-16) in the same spin system were consistent for the presence of $\beta$-substituted furan ring (fragment $\mathrm{D}$ ). The remaining signals were attributed to two epoxide protons as an AX system $\left(\delta 3.51\right.$ and $\left.2.19, J_{\mathrm{AX}}=5.7 \mathrm{~Hz}, \mathrm{H}_{2}-18\right)$ of an oxirane, two downfield-shifted oxymethylene protons as an $\mathrm{AB}$ system $\left(\delta 5.40\right.$ and $4.99, J_{\mathrm{AB}}=13.0$ $\left.\mathrm{Hz}, \mathrm{H}_{2}-19\right)$ with an acetoxyl group ( $\delta 2.01 \mathrm{~s}$ ) which were assigned to the molecular fragments $\mathrm{E}$ and $\mathrm{F}$, respectively. The ${ }^{13} \mathrm{C}-\mathrm{NMR}$ spectrum additionally indicated the presence of three carbonyl fuctionalities at $\delta 207.1(\mathrm{C}-6), 176.6(\mathrm{C}-20)$ (fragments $\mathrm{G}$ and $\mathrm{H}$, resp.) and $170.1\left(\mathrm{COCH}_{3}\right)$. Three carbonyl resonances and two endocyclic double bonds of the furan ring clearly suggested the presence of a pentacyclic structure for 5. Intermolecular connectivities were established by the help of a longrange ${ }^{13} \mathrm{C}-{ }^{1} \mathrm{H}$ heteronuclear correlation (HMBC) experiment (Figure 4). The long-range correlations from $\mathrm{C}-5$ to $\mathrm{H}_{2}-18, \mathrm{H}_{2}-19$, and from $\mathrm{C}-4$ and $\mathrm{C}-6$ to $\mathrm{H}_{2}-19$, as well as from C-9, C-10, and C-29 to $\mathrm{H}_{2-}$ 11 , generated the $\mathrm{A}$ and $\mathrm{B}$ fragments of a decalin moiety which bears an oxirane $(\mathrm{C}-18)$ at $\mathrm{C}-4$, acylated hydroxymethylene (C-19) at C-5, and a $\gamma$-spirolactone moieties at C-9. (fragments E, F and C, respectively). Furthermore, the long-range correlations from $\mathrm{C}-13$ to $\mathrm{H}-16$ and $\mathrm{H}-12$ were evident for the location of the furan ring. The core decalin moiety in clerodane-type diterpenoids consisting of a 5:10 trans ring junction is characteristic for the family Lamiaceae [21] and Teucrium species [5]. This data was in good agreement with those reported for a clerodane-type diterpene, teucrin H3 [19acetoxy-4 $\alpha, 18: 15,16$-diepoxy-6-keto-neo-cleroda-13(16),14-dien-20,12S-olide] isolated from $T$. hyrcanicum [22]. Teucrin H3 was also reported from T. gnapholides and named as 19-acetylgnaphalin [23]. Malakov and his friends (1979) reported this diterpenoid from T. polium using both trivial names, teucrin $\mathrm{H} 3$ and 19-acetylgnaphalin Based on these results, the structure of $\mathbf{5}$ was established as teucrin $\mathrm{H} 3$ [24].

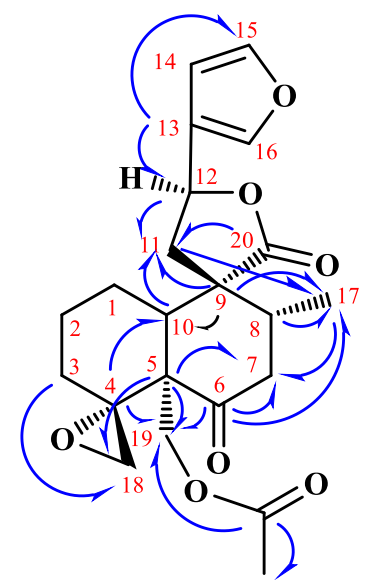

Figure 4. The significant ${ }^{13} \mathrm{C}-{ }^{1} \mathrm{H}$ long-range heteronuclear correlations observed for 5

Compound $6\left\{[\alpha]_{\mathrm{D}}^{20}+47.6^{\circ}\left(\mathrm{c}=0.084, \mathrm{CHCl}_{3}\right)\right\}$ had the molecular formula $\mathrm{C}_{22} \mathrm{H}_{28} \mathrm{O}_{7}$ as determined by the positive ion HR-MS which exhibited a quasimolecular ion $[\mathrm{M}+\mathrm{Na}]^{+}$peak at $\mathrm{m} / \mathrm{z}$ 427,1719 which corresponds with the molecular formula $\mathrm{C}_{22} \mathrm{H}_{28} \mathrm{O}_{7} \mathrm{Na}$ with a $\mathrm{Mr}$ of 427,1733 and 9 degrees of unsaturation. This result indicated the molecular weight of 6 to be $404,1835\left(\mathrm{C}_{22} \mathrm{H}_{28} \mathrm{O}_{7}\right)$. The difference in molecular weight between the compounds $\mathbf{5}$ and $\mathbf{6}$ is two daltons. The ${ }^{1} \mathrm{H}-\mathrm{NMR}$ spectrum of 6 revealed a secondary methyl $(\delta 0.95 \mathrm{~d}, J=6.5 \mathrm{~Hz}, \mathrm{Me}-17)$, an acetoxyl group $(\delta 2.01 \mathrm{~s})$, a geminal proton of a hydroxyl group $(\delta 3.59 \mathrm{dd}, J=12.7$ and $2.8 \mathrm{~Hz}, \mathrm{H}-6)$, two epoxide protons as an AX system $\left(\delta 3.16\right.$ and $\left.2.40, J_{\mathrm{AX}}=2.8 \mathrm{~Hz}, \mathrm{H}_{2}-18\right)$, and two oxymethylene protons as an AB system $(\delta$ 4.94 and $\left.4.64, J_{\mathrm{AB}}=13.1 \mathrm{~Hz}, \mathrm{H}_{2}-19\right)$. A proton signal at $\delta 5.28(\mathrm{t}, J=8.5 \mathrm{~Hz}, \mathrm{H}-12)$ and two protons at $\delta 2.29\left(2 \mathrm{H}\right.$, br d, $\left.J=8.5 \mathrm{~Hz}, \mathrm{H}_{2}-11\right)$ were observed in the same spin system. Three protons at $\delta 6.31$, 7.36 and 7.37 (each $1 \mathrm{H}$, br s, H-14, H-15 and H-16) in the same spin system were consistent for the 
presence of $\beta$-substituted furan ring. The difference between 5 and $\mathbf{6}$ was due to proton and carbon resonances arising from the molecular fragment B. Compound $\mathbf{6}$ was found to have a hydroxyl group at C-6 ( $\delta 3.59$ ) instead of a ketone function of 5. NMR data of 6 (Tables 3 and 4) was in good accordance with those reported for teucjaponin B, a (12S)-neoclerodan-20,12-olide-type diterpenoid [25]. Moreover, in the NOESY experiment performed with $\mathbf{5}$ and $\mathbf{6}$, the lack of NOE-cross-peaks between $\mathrm{H}_{3}-17 / \mathrm{H}-12$ supported the $\mathrm{C}-12(S)$ configuration for both [26]. Consequently, the structure of 6 was identified as 19-acetoxy-4 $\alpha, 18: 15,16$-diepoxy-6 $\alpha$-hydroxy-neo-cleroda-13(16),14-diene20,12(S)-olide.

Table 3. ${ }^{1} \mathrm{H}-\mathrm{NMR}$ data for diterpenoids, 5 - 8

\begin{tabular}{|c|c|c|c|c|}
\hline & 5 & 6 & 7 & 8 \\
\hline $\mathrm{C} / \mathrm{H}$ & $\delta_{\mathrm{H}} \mathbf{p p m}, J(\mathrm{~Hz})$ & $\delta_{\mathrm{H}} \mathbf{p p m}, \mathrm{J}(\mathrm{Hz})$ & $\delta_{\text {H }}$ ppm, J (Hz) & $\delta_{\mathbf{H}} \mathbf{p p m}, \mathbf{J}(\mathbf{H z})$ \\
\hline $1 \mathrm{a}$ & 1.85 brd, & 1.82 brd (12.0) & $2.03 \dagger$ & $2.03 \mathrm{~m}$ \\
\hline $1 b$ & $1.71 \mathrm{ddd}$ & $1.68 \mathrm{dd}(12.0,3.6)$ & $1.73 \dagger$ & $1.54 \mathrm{~m}$ \\
\hline $2 \mathrm{a}$ & $1.97 \mathrm{~m}$ & $1.99 \dagger$ & $1.90 \mathrm{~m}$ & $1.92 \mathrm{~m}$ \\
\hline $2 b$ & $1.47 \mathrm{~m}$ & $1.45 \dagger$ & $1.42 \mathrm{~m}$ & $1.50 \mathrm{~m}$ \\
\hline $3 a$ & $2.43 \mathrm{~m}$ & 2.17 ddd "bt" (12.8) & $2.10 \dagger$ & $2.15 \mathrm{~m}$ \\
\hline $3 b$ & $0.94 \mathrm{~m}$ & 1.04 brd (12.8) & 1.04 brd (12.9) & $1.05 \mathrm{~m}$ \\
\hline 6 & - & $3.59 \mathrm{dd}(12.7,2.8)$ & $4.74 \mathrm{dd}(10.6,5.0)$ & $4.76 \mathrm{dd}(12.1,4.8)$ \\
\hline $7 \mathrm{a}$ & $3.47 \mathrm{t}(13.5)$ & 2.08 ddd $(15.3,12.7)$ & $1.73^{\dagger}$ & $1.63 \mathrm{~m}$ \\
\hline $7 b$ & $2.08 \mathrm{dd}(13.5,3.8)$ & $1.60 \mathrm{dt}(12.7,12.7,2.3)$ & $1.52 \operatorname{ddd}(9.5,9,5,4.3)$ & $1.51 \mathrm{~m}$ \\
\hline 8 & $1.94^{\dagger}$ & $1.54 \mathrm{~m}$ & $1.73^{\dagger}$ & $1.78 \mathrm{~m}$ \\
\hline 10 & $2.05 \mathrm{dd}(13.4,3.7)$ & $1.59^{\dagger}$ & $1.98 \mathrm{dd}(12.3,2.3)$ & $2.02 \mathrm{dd}(13.0,3.0)$ \\
\hline $11 \mathrm{a}$ & \multirow{2}{*}{$2.38 \mathrm{dd}(8.5,5.7)$} & \multirow{2}{*}{2.29 brd (8.5) } & $2.14 \mathrm{dd}(15.8,7.0)$ & $1.94 \dagger$ \\
\hline $11 b$ & & & $1.79 \mathrm{dd}(15.8,2.2)$ & $1.60 \mathrm{dd}(16.0,2.3)$ \\
\hline 12 & $5.39 \mathrm{t}(8.6)$ & $5.28 \mathrm{t}(8.5)$ & $4.86 \mathrm{dd}(8.9,2.0)$ & $4.79 \mathrm{dd}(8.9,2.3)$ \\
\hline 14 & 6.32 brs & $6.31 \mathrm{brs}$ & $6.41 \mathrm{t}(1.2)$ & $6.39 \mathrm{~d}(1.5)$ \\
\hline 15 & 7.40 brs & $7.36^{\dagger}$ & $7.39 \dagger$ & $7.39 \mathrm{t}(1.5)$ \\
\hline 16 & $7.38 \mathrm{brs}$ & $7.37^{\dagger}$ & $7.39 \dagger$ & $7.37 \mathrm{brs}$ \\
\hline 17 & $1.00 \mathrm{~d}(6.7)$ & $0.95 \mathrm{~d}(6.5)$ & $0.92 \mathrm{~d}(6.2)$ & $0.78 \mathrm{~d}(6.7)$ \\
\hline $18 \mathrm{a}$ & $3.51 \mathrm{~d}(5.7)$ & $3.16 \mathrm{~d}(2.8)$ & $3.01 \mathrm{dd}(4.0,2.2)$ & $3.01 \mathrm{dd}(4.0,2.4)$ \\
\hline $18 \mathrm{~b}$ & $2.19 \mathrm{~d}(5.7)$ & $2.40 \mathrm{~d}(2.8)$ & $2.21 \mathrm{~d}(4.0)$ & $2.22 \mathrm{~d}(4.0)$ \\
\hline $19 \mathrm{a}$ & $5.40 \mathrm{~d}(13.0)$ & $4.94 \mathrm{~d}(13.1)$ & $4.89 \mathrm{~d}(12.0)$ & $4.86 \mathrm{~d}(12.1)$ \\
\hline $19 b$ & $4.99 \mathrm{~d}(13.0)$ & $4.64(13.1)$ & $4.42 \mathrm{~d}(12.0)$ & $4.39 \mathrm{~d}(12.1)$ \\
\hline 20 & - & - & $3.59 \mathrm{brs}$ & $0.71 \mathrm{~s}$ \\
\hline $\mathrm{CO} \underline{C} \mathrm{H}_{3}$ & $2.01 \mathrm{~s}$ & $2.01 \mathrm{~s}$ & $2.10 \mathrm{~s}$ & 2.10 \\
\hline $\mathrm{CO} \underline{C H}_{3}$ & & & $1.94 \mathrm{~s}$ & 1.95 \\
\hline
\end{tabular}

"All assignments are based on 2D-NMR experiments (COSY, HSQC and HMBC). ( $\square \mathrm{H}: 500 \mathrm{MHz}, \mathrm{CDCl}_{3}$ ).

$\dagger$ Signal pattern unclear due to overlapping

Compound 7 had the molecular formula $\mathrm{C}_{24} \mathrm{H}_{34} \mathrm{O}_{8}$, as determined by HR-MS. The positive-ion HR-MS showed a quasimolecular ion peak at $\mathrm{m} / \mathrm{z}$ 473,2136 [M+Na] ${ }^{+}$(calc. for $\mathrm{C}_{24} \mathrm{H}_{34} \mathrm{O}_{8} \mathrm{Na}$ ), corresponding to the molecular formula $\mathrm{C}_{24} \mathrm{H}_{34} \mathrm{O}_{8}$ ( $\mathrm{Mr}$ of 450,2254) and 8 degrees of unsaturation. The assignment of all proton and carbon resonances were based on 2D-NMR (COSY, HSQC and HMBC) experiments which were characteristic for furanoid diterpene such as $\mathbf{5}$ and $\mathbf{6}$ (Tables 3 and 4). Two carbonyl resonances and two endocyclic double bonds of the furan ring clearly suggested the presence of a tetracyclic structure for 7 . In the ${ }^{1} \mathrm{H}$-NMR spectrum of 7 , a secondary methyl $(\delta 0.92, \mathrm{~d}, J=6.2$ 
$\left.\mathrm{Hz}, \mathrm{H}_{3}-17\right)$, two acetoxymethyl ( $\delta 1.94$ and 2.10 , each $\left.3 \mathrm{H}, \mathrm{s}\right)$, two protons as an AX system of the oxirane ring ( $\delta 3.01$ and 2.21 , both $\mathrm{d}, J_{\mathrm{Ax}}=4.0 \mathrm{~Hz}, \mathrm{H}_{2}-18$ ), a broad singlet with two proton intensity of a hydroxymethylene signal $\left(\delta 3.59, \mathrm{H}_{2}-20\right)$, two protons as an $\mathrm{AB}$ system $(\delta 4.89$ and 4.42 , both $\mathrm{d}$, $\left.J_{\mathrm{AB}}=12.0 \mathrm{~Hz}, \mathrm{H}_{2}-19\right)$ and an oxymethine proton $(\delta 4.74$, dd, $J=10.6$ and $5.0 \mathrm{~Hz})$ were clearly observed. The remaining signals were arising from an $\mathrm{ABX}$ system at $\delta 2.14,1.79$ (each $1 \mathrm{H}$, each dd, $\left.\mathrm{H}_{2}-11\right)$ and $4.86(1 \mathrm{H}, \mathrm{dd}, \mathrm{H}-12)$. By the help of an $\mathrm{HMBC}$ experiment, intermolecular connectivites were established (Figure 5). NOESY spectrum showed the cross-peaks between $\mathrm{H}_{2}-19 / \mathrm{H}_{2}-20$ and $\mathrm{H}_{2}-$ $19 / \mathrm{H}_{3}-17$ indicating that these protons were the same side of the decaline moiety. On the other hand, the nOe correlations observed between the $\mathrm{H}_{2}-18 / \mathrm{H}-6$ and $\mathrm{H}-6 / \mathrm{H}-10$ indicated that these protons were on the reverse side of the trans-decaline ring. These observations and full NMR data and the optical rotation value $\left\{[\alpha]_{\mathrm{D}}{ }^{20}-8.8^{\circ}\left(\mathrm{c}=0.157, \mathrm{CHCl}_{3}\right)\right\}$ were in superimposable in accordance with those reported for teucretol [6 $\alpha, 19$-diacetoxy-4 $\alpha, 18: 15,16$-diepoxy-12S,20-dihydroxy-neo-cleroda13(16),14diene] isolated from the same plant, Teucrium creticum collected from (Cyprus) [27].

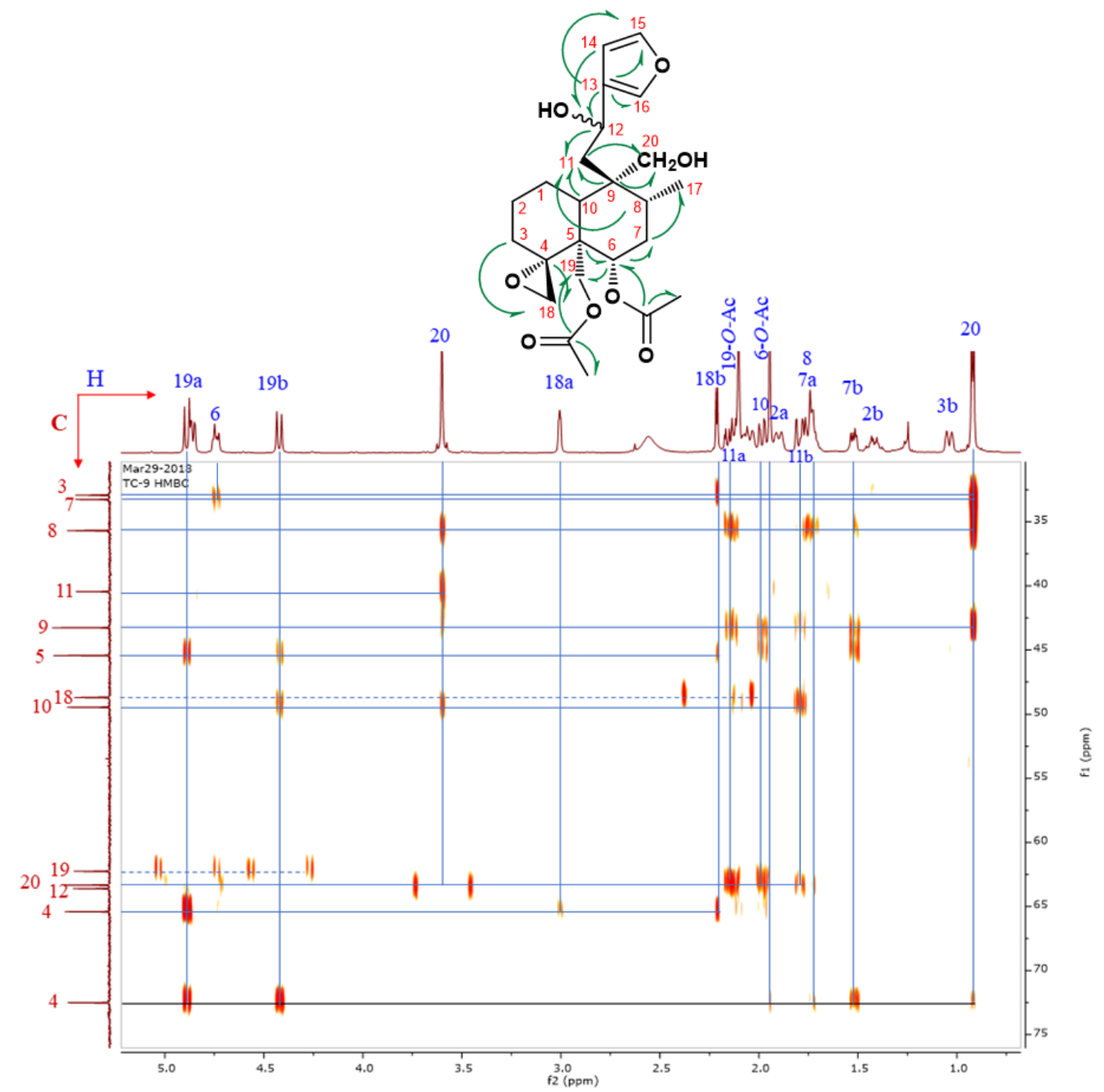

Figure 5. The Significant ${ }^{13} \mathrm{C}-{ }^{1} \mathrm{H}$ Long-range heteronuclear correlations (HMBC) observed for 7 $\left({ }^{1} \mathrm{H}: 0.50-5.25 \mathrm{ppm} ;{ }^{13} \mathrm{C}: 30-75 \mathrm{ppm}\right)$

Compound 8 gave a a quasimolecular ion peak in its positive-ion HR-MS at m/z 457,2191 $[\mathrm{M}+\mathrm{Na}]^{+}$(calc. for $\mathrm{C}_{24} \mathrm{H}_{34} \mathrm{O}_{7} \mathrm{Na}$ ), corresponding to the molecular formula $\mathrm{C}_{24} \mathrm{H}_{34} \mathrm{O}_{7}(\mathrm{Mr}$ of 457,2202) and 8 degrees of unsaturation. The ${ }^{13} \mathrm{C}$ NMR spectrum displayed 22 signals due to four methyl (one 
secondary methyl, one tertiary methyl and two acetoxymethyl), six methylenes (two oxygenated), seven methine (one oxygenated, three olefinic) and five quaternary (two oxygenated, one olefinic, two carbonyl) carbon atoms (Table 1). This data was indicative for a tetracyclic structure for $\mathbf{8}$. The ${ }^{1} \mathrm{H}-$ NMR spectrum of $\mathbf{8}$ showed the presence of three olefinic protons, four methyl resonances (one secondary, one tertiary and two acetoxy) and a pair of two hydroxymethylene signals which were very similar to those observed for 7 except the presence of a tertiary methyl resonance $\left(\delta 0.71 \mathrm{~s}_{3} \mathrm{H}_{3}-20\right)$ and the lack of hydroxymethylene resonance assigned as $\mathrm{H}_{2}-20$. The 2D-NMR experiments (COSY, HSQC, HMBC and NOESY) pointed out the two of four rings were arising from the trans-decalin moiety, the third one belonged the oxirane ring and the last one was due to the furan ring. These molecular fragments were clearly assembled into the basic framework of $\mathbf{8}$ from the results of the HMBC experiment. The relative stereochemistry of the oxirane ring, acetylated hydroxymethylene and hydroxymethine functionalities, the tertiary and secondary methyl groups was established by the help of NOESY experiment. All these data as well as optical rotation value $\left\{[\alpha]_{\mathrm{D}}{ }^{20}-9.2\right.$ (c. 0.348 ,

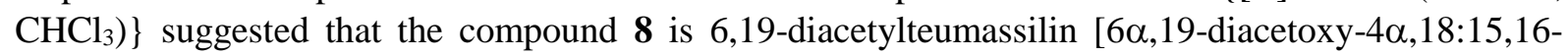
diepoxy-12S-hydroxy-neo-cleroda-13(16),14diene] isolated from Teucrium massilense [28].

Table 4. ${ }^{13} \mathrm{C}-\mathrm{NMR}$ data for diterpenoids, $5-\mathbf{8}$

\begin{tabular}{|c|c|c|c|c|c|c|c|c|}
\hline \multirow[b]{2}{*}{$\mathrm{C} / \mathrm{H}$} & \multicolumn{2}{|c|}{5} & \multicolumn{2}{|c|}{6} & \multicolumn{2}{|c|}{7} & \multicolumn{2}{|c|}{8} \\
\hline & DEPT & $\delta_{\mathrm{C}} \mathbf{p p m}$ & DEPT & $\delta_{\mathrm{c}} \mathrm{ppm}$ & DEPT & $\delta_{\mathrm{C}} \mathbf{p p m}$ & DEPT & $\delta_{\mathrm{C}} \mathbf{p p m}$ \\
\hline 1 & $\mathrm{CH}_{2}$ & 23.5 & $\mathrm{CH}_{2}$ & 22.6 & $\mathrm{CH}_{2}$ & 22.7 & $\mathrm{CH}_{2}$ & 21.5 \\
\hline 2 & $\mathrm{CH}_{2}$ & 24.8 & $\mathrm{CH}_{2}$ & 25.0 & $\mathrm{CH}_{2}$ & 25.2 & $\mathrm{CH}_{2}$ & 24.8 \\
\hline 3 & $\mathrm{CH}_{2}$ & 32.8 & $\mathrm{CH}_{2}$ & 31.3 & $\mathrm{CH}_{2}$ & 32.9 & $\mathrm{CH}_{2}$ & 32.8 \\
\hline 4 & $\mathrm{C}$ & 54.2 & $\mathrm{C}$ & 66.6 & $\mathrm{C}$ & 65.4 & $\mathrm{C}$ & 65.2 \\
\hline 5 & $\mathrm{C}$ & 61.3 & $\mathrm{C}$ & 45.3 & $\mathrm{C}$ & 45.4 & $\mathrm{C}$ & 45.5 \\
\hline 6 & $\mathrm{C}$ & 207.1 & $\mathrm{CH}$ & 73.4 & $\mathrm{CH}$ & 72.5 & $\mathrm{CH}$ & 72.5 \\
\hline 7 & $\mathrm{CH}_{2}$ & 43.5 & $\mathrm{CH}_{2}$ & 33.8 & $\mathrm{CH}_{2}$ & 33.3 & $\mathrm{CH}_{2}$ & 33.0 \\
\hline 8 & $\mathrm{CH}$ & 41.6 & $\mathrm{CH}$ & 38.3 & $\mathrm{CH}$ & 35.7 & $\mathrm{CH}$ & 35.1 \\
\hline 9 & $\mathrm{C}$ & 51.7 & $\mathrm{C}$ & 51.1 & $\mathrm{C}$ & 43.3 & $\mathrm{C}$ & 39.0 \\
\hline 10 & $\mathrm{CH}$ & 55.6 & $\mathrm{CH}$ & 52.4 & $\mathrm{CH}$ & 49.5 & $\mathrm{CH}$ & 48.6 \\
\hline 11 & $\mathrm{CH}_{2}$ & 43.7 & $\mathrm{CH}_{2}$ & 43.5 & $\mathrm{CH}_{2}$ & 40.5 & $\mathrm{CH}_{2}$ & 44.8 \\
\hline 12 & $\mathrm{CH}$ & 72.0 & $\mathrm{CH}$ & 71.5 & $\mathrm{CH}$ & 63.3 & $\mathrm{CH}$ & 63.0 \\
\hline 13 & $\mathrm{C}$ & 124.9 & $\mathrm{C}$ & 125.1 & $\mathrm{C}$ & 130.8 & $\mathrm{C}$ & 131.0 \\
\hline 14 & $\mathrm{CH}$ & 107.9 & $\mathrm{CH}$ & 108.0 & $\mathrm{CH}$ & 108.4 & $\mathrm{CH}$ & 108.3 \\
\hline 15 & $\mathrm{CH}$ & 139.6 & $\mathrm{CH}$ & 144.2 & $\mathrm{CH}$ & 143.6 & $\mathrm{CH}$ & 143.6 \\
\hline 16 & $\mathrm{CH}$ & 144.4 & $\mathrm{CH}$ & 139.6 & $\mathrm{CH}$ & 138.4 & $\mathrm{CH}$ & 138.3 \\
\hline 17 & $\mathrm{CH}_{3}$ & 17.1 & $\mathrm{CH}_{3}$ & 16.5 & $\mathrm{CH}_{3}$ & 16.9 & $\mathrm{CH}_{3}$ & 15.5 \\
\hline 18 & $\mathrm{CH}_{2}$ & 48.6 & $\mathrm{CH}_{2}$ & 48.5 & $\mathrm{CH}_{2}$ & 48.7 & $\mathrm{CH}_{2}$ & 48.5 \\
\hline 19 & $\mathrm{CH}_{2}$ & 62.1 & $\mathrm{CH}_{2}$ & 61.7 & $\mathrm{CH}_{2}$ & 62.3 & $\mathrm{CH}_{2}$ & 61.9 \\
\hline 20 & $\mathrm{C}$ & 176.6 & $\mathrm{C}$ & 176.0 & $\mathrm{CH}_{2}$ & 63.6 & $\mathrm{CH}_{3}$ & 17.3 \\
\hline $\mathrm{COCH}_{3}$ & $\mathrm{C}$ & 170.8 & $\mathrm{C}$ & 170.7 & $\mathrm{C}$ & 170.3 & $\mathrm{C}$ & 170.1 \\
\hline $\mathrm{CO}^{\mathrm{C}} \mathrm{H}_{3}$ & $\mathrm{CH}_{3}$ & 20.9 & $\mathrm{CH}_{3}$ & 21.3 & $\mathrm{CH}_{3}$ & 21.3 & $\mathrm{CH}_{3}$ & 21.3 \\
\hline $\mathrm{COCH}_{3}$ & & & & & $\mathrm{C}$ & 170.1 & $\mathrm{C}$ & 170.0 \\
\hline $\mathrm{CO} \underline{\mathrm{C}} \mathrm{H}_{3}$ & & & & & $\mathrm{CH}_{3}$ & 21.2 & $\mathrm{CH}_{3}$ & 21.2 \\
\hline
\end{tabular}

${ }^{*} \delta_{\mathrm{H}}: 125 \mathrm{MHz}, \mathrm{CDCl}_{3}$. 


\section{Conclusion}

Present study resulted in the isolation of two iridoids which are 8-O-acetylharpagide (1) and teuhircoside (2); in addition to two phenylethanoid glycosides which are verbascoside (3) and lavandulifolioside (4), and finally four neoclerodane-type diterpenoids; teucrin H3 (= 19acetylgnaphalin) (5), teucjaponin B (6), teucretol (7), and diacetylteumassilin (10). All findings are isolated from T. creticum (Section: Teucrium): which is named as "Girit Kurtlucasl" in Turkish [29].

First of all with regards to iridoids; previous research reports limited structural diversity of the iridoids in Teucrium species. [30-35]. In this respect it is important to note that within this recent study, a potential active metabolite group of iridoids are isolated.which are harpagide, 8- $O$ acetylharpagide, teuhircoside and teucardoside.

Secondly, with regards to the phenylethanoid glycosides, acteoside (3) and lavandulifolioside (4) were isolated. As a diglycoside, acteoside (3) is the predominant compound in plants rich in phenylethanoid glycosides. Lavandulifolioside (4) has a triglycosidic structure similar poluimoside [9, 36], and teucrioside [10, 37, 38] which were reported from other T. polium (Section: Polium) and T. chamaedrys (Section: Chamaedrys), respectively. Interestingly, the glycosidation pattern of lavandulifolioside shows similarity to those of teucrioside. The third sugar on the rhamnose unit of acteoside is xylose for lavandulifolioside while it is a rare sugar lyxose for teucrioside. In previous researche, a series of pharmacological and biological activities of many medicinal plants have been ascribed to the presence of phenylethanoid glycosides [39-42]. In addition, a recent study reported the neuroprotective actions of echinacoside as a potential therapeutic agent for preventing the progression of Alzheimer disease [43]. Phenylethanoid (phenylpropanoid) glycosides as caffeoyl sugar esters are found in many gamopetalous plants [44]. In chemotaxonomical studies, the subfamily division of the Lamiaceae has been based on two chemical characteristics, which are rosmarinic acid and caffeic acid sugar esters, or, phenylethanoid glycosides [45].

Finally, in this study diterpenoids: 5-8 were isolated from T. creticum. They exhibit neoclerodane skeleton. Diterpenoids from the Teucrium species exhibit neo-clerodane skeleton, which are chemotaxonomic markers, and, isolated from the aerial parts of plants [5, 21]. As documented by previous research, rearranged abietane-type diterpenes are isolated from the roots of Teucrium species. Some neo-clerodane diterpenoids, especially furan-containing diterpenoids, are highly hepatotoxic causing hepatic necrosis in mice. They have also been thought to cause, or provoke chronic hepatitis, or and cirrhosis in humans [21, 46, 47]. Current research on the genus also reported hepatotoxicity and, biological activity [48], as well as diterpenoids [49] performed on the Teucrium species.

Former studies conducted on different Teucrium species report flavonoids, as other phenolic metabolites, sesquiterpenes, triterpenes steroids, as well as monoterpenes as the constituents of volatile oils, have been reported. Flavonoids are mostly apigenin and luteolin type flavones, quercetin type flavonols and their 6-OH or 8-OH derivatives and glycosides. Most of the flavon and flavonol are methoxylated [50, 51]. Many activities such as antioxidant, antiinflammatory and antirheumatic, antihistaminic, spasmolitic, antigonadotropic, vasodilatory, sucrase inhibitory, inhibitory, DNA polymerase, hepatoprotective, antimicrobial, antiallergic are attributed to the flavonoids of Teucrium species [51]. Linalool, $\beta$-caryophyllene and caryophyllene oxide and spathulenol were found as major constituents of flower, leaf and fruit oils of T. creticum collected from Cyprus [52]. A recent study has reported the significant antimicrobial activity of aqueous and methanolic extracts of the leaves of $T$. creticum against eight multidrug-resistant bacteria isolated at an oncology department and reference bacterial and fungal strains [53].

Having said that, as a final remark, it is important to recall that the consumption of herbal products, in this case of Teucrium species, needs further attention due to the potential toxic metabolites, in spite of the presence of highly effective metabolites such as isoprenoids, flavonoids and phenylethanoid glycosides.

\section{Acknowledgements}

The authors kindly thank Anzarul Haque for 1D and 2D NMR measurements of the diterpenoids and Ayman Salkini for HRMS (Prince Sattam Bin Abdulaziz University, Saudi Arabia). 
The authors also thank to Prof. Dr. Hakan Gögen (Ankara University, Faculty of Pharmacy, Ankara, Turkey) for the 1D and 2D NMR measurements of the iridoids and phenylethanoid glycosides.

\section{Supporting Information}

Supporting information accompanies this paper on http://www.acgpubs.org/journal/records-ofnatural-products

\section{ORCID}

Azmi Hanoğlu: 0000-0002-7586-9080

Duygu Yiğit Hanoğlu: 0000-0003-1345-4768

Nilay Demirel: 0000-0002-9262-099X

Hasan Soliman Yusufoğlu: 0000-0001-7062-8029

İhsan Çalış: 0000-0001-5489-3420

\section{References}

[1] F. Celep and T. Dirmenci (2017). Systematic and biogeographic overview of Lamiaceae in Turkey, Nat. Vol. Essent. Oils. 4, 14-27.

[2] B. Li, P.D. Cantino, R.G. Olmstead, G.L.C. Bramley, C.L. Xiang, Z.H. Ma, Y.H. Tan and D.X. Zhang (2016). A large-scale chloroplast phylogeny of the Lamiaceae sheds new light on its subfamilial classification, Sci. Rep. 6, 1-18.

[3] R.D. Meikle (1985). Flora of cyprus. The bentham-moxon trust, royal botanic gardens, kew, 2, 8331969. ISBN 09504876 43, Clark Constable, Edinburgh, London, Melbourne.

[4] J. Jakupovic, R. N. Baruah, F. Bohlmann and W. Quack (1985). New clerodane derivatives from Teucrium scordium, Planta Med. 341- 342.

[5] A. Ulubelen, G. Topçu and U. Sönmez (2000). Chemical and biological evaluation of genus Teucrium. In: Studies in Natural Products Chemistry, ed: Atta-ur Rahman, Elsevier Science, Amsterdam, Netherlands, Vol.23, pp $591-648$.

[6] N.A. Bukhari, R.A. Al-Otaibi and M. M. Ibhrahim (2015). Biodiversity characteristics of Teucrium Polium species in Saudi Arabia, Saudi J. Biol. Sci. 22, 181-185.

[7] N.A. Jaradat (2015). Review of the taxonomy, ethnobotany, phytochemistry, phytotherapy and phytotoxicity of germander plant (Teucrium polium L.), Asian J. Pharm. Clin. Res. 8, 13-19.

[8] Z. Yaniv, A. Dafni, J. Friedman and D. Palevitch (1987). Plants used for the treatment of diabetes in Israel, J. Ethnopharmacol. 19: 145-151.

[9] C. Andary, R. Wylde, A. Heitz, J.P. Rascol, J.L. Roussel and C. Laffite (1985). Poliumoside, a caffeic glycoside ester from Teucrium belion, Phytochemistry 24, 362-364.

[10] G.A. Gross, M.F. Lahloub, C. Anklin, H.-R. Schulten and O. Sticher (1988). Teucrioside, a phenylpropanoid glycoside from Teucrium Chamaedrys, Phytochemistry 27, 1459-1463.

[11] F. Antognoni, C. Iannello, M. Mandrone, M. Scognamiglio, A. Fiorentino, P.P. Giovannini and F. Poli (2012). Elicited Teucrium chamaedrys cell cultures produce high amounts of teucrioside, but not the hepatotoxic neo-clerodane diterpenoids, Phytochemistry 81, 50-59.

[12] S. Pacifico, B. D’Abrosca, M. Scognamiglio, G. D’Angelo, M. Gallicchio, S. Galasso, P. Monaco and A. Fiorentino (2012). NMR-based metabolic profiling and in vitro antioxidant and hepatotoxic assessment of partially fractions from golden germander (Teucrium polium L.) methanolic extract, Food Chem, 135, 1957-1967.

[13] M. Bruno, S. Rosselli, A. Maggio, F. Piozzi, L. Scaglioni, N.A. Arnold and M.S.J. Simmonds (2004). Neoclerodanes from Teucrium orientale, Chem. Pharm. Bull. 52, 1497-1500.

[14] M.S. Stankovic, M.G. Curcic, J.B. Zizic, M.D. Topuzovic, S.R. Solujic and S.D. Markovic (2011). Teucrium plant species as natural sources of novel anticancer compounds: Antiproliferative, proapoptotoic and antioxidant properties, Int. J. Mol. Sci. 12, 4190-4205.

[15] Y. Takeda, S. Tsuchida and T. Fujita (1987). Four new iridoid glucoside $p$-Coumaroyl esters from Ajuga decumbens, Phytochemistry 26, 2303-2306.

[16] M. Jeker, O. Sticher, İ. Çalıs and P. Rüedi (1989). Allobetonicoside and 6-O-Acetylmioporoside from Betonica officinalis L., Helv. Chim. Acta. 72, 1787-1791.

[17] J. Ruhdorfer and H. Rimpler (1981). Iridoide aus einigen Teucrium- und Ajuga-Arten, Z. Naturforsch. C. 36, 697-707. 
[18] J. Ruhdorfer and H. Rimpler (1981). Teucardosid, ein neues iridoid aus Teucrium arduini L. und Teucrium hircanicum L., Tetrahedron Lett. 22, 839-842.

[19] O. Sticher and M. F. Lahloub (1982). Phenolic glycosides of Paulownia tomentosa bark, Planta Med. 46, 145-148.

[20] A.A. Başaran, İ. Çalış, C. Anklin, S. Nishibe and O. Sticher (1988). Lavandulifolioside: A new phenylprophanoid glycoside from Stachys lavandulifolia, Hel. Chim. Acta 71, 1483-1490.

[21] R. Li, S. L. Morris-Natschkeb and K. H. Lee (2016). Clerodane diterpenes: Sources, structures and biological activities, Nat. Prod Rep. 33, 1166-1226.

[22] E. Gacz-Baitz, L. Radics, G.B. Ogenessian and V.A. Mnatsakanian (1978). Teucrins H1 - H4, novel clerodane-type diterpenes from Teucrium hyrcanicum, Phytochemistry 17, 1967-1973.

[23] P.Y. Malakov, G.Y. Papanov and N.M. Mollov (1979). Furanoid diterpenes in the bitter fraction of Teucrium polium L., Z. Naturforsch. 34b, 1570-1572.

[24] G. Savona, M. Paternostro and F. Piozzi (1979). New furanoid diterpenes from Teucrium gnaphalodes L'Her., Tetrahedron Lett. 4, 379 - 382.

[25] T. Miyase, H. Kawasaki, T. Noro, A. Ueno, S. Fukushima and T. Takemoto (1981). Studies on the furanoid diterpenes from Teucrium japonicum Houtt, Chem. Pharm. Bull. 29, 3561-3564.

[26] J. Fayos, F. Fernandez-Gadea, C. Pascaul, A. Perales, F. Piozzi, M. Rico, B. Rodriguez and G. Savona (1984). Correct structures of montanin C, teupolin I, and 12-epi-teucvin, three (12R)-Neoclerodan-2012-olides isolated from the Teucrium species, J. Org. Chem. 49, 1789-1793.

[27] G. Savona, F. Piozzi, M. Bruno, G. Dominguez, B. Rodriguez and O. Servettaz (1987). Teucretol, a Neo-Clerodane diterpenoid from Teucrium creticum, Phytochemistry 26, 3285-3288.

[28] G. Savona, M. Bruno, F. Piozzi, O. Servettaz and B. Rodriguez (1984). Neo-Clerodane diterpenoids from Teucrium massiliense, Phytochemistry 23, 849-852.

[29] D.E. Viney (1994). An Illustrated Flora of North Cyprus, Vol 1. Koeltz Scientific Books, Koenigstein, 697.

[30] J.E. El-Naggar and J. L. Beal (1984). Iridoids. A Review. J. Nat. Prod. 43, 649-707.

[31] C.A. Boros and F.R. Stermitz (1990). Iridoids an Update Review, Part I. J. Nat. Prod. 53, 1055-1147.

[32] C.A. Boros and F.R. Stermitz (1991). Iridoids an Update Review, Part II. J. Nat. Prod. 54, 1173-1246.

[33] B. Dinda, S. Debnath and Y. Harigaya (2007). Naturally occurring iridoids, A Review, Part 1. Chem. Pharm. Bull. 55(2), 159-222.

[34] B. Dinda, S. Debnath and Y. Harigaya (2007). Naturally occurring secoiridoids and bioactivity of naturally occurring iridoids and secoiridoids, A Review, Part 2. Chem. Pharm. Bull. 55, 689-728.

[35] B. Dinda, D.R. Chowdhury and B.C. Chandra (2009). Naturally occurring iridoids, secoiridoids and their bioactivity, An updated review, part 3. Chem. Pharm. Bull. 57, 765-796.

[36] E. Bedir, D. Tasdemir, İ. Çaliş, O. Zerbe and O. Sticher (1999). Neo-clerodane diterpenoids from Teucrium polium, Phytochemistry 51, 921-925.

[37] E. Bedir, R. Manyam and I. A. Khan (2003). Neo-clerodane diterpenoids and phenylethanoid glycosides from Teucrium chamaedrys L., Phytochemistry 63, 977-983.

[38] M. Elmastas, R. Erenler, B. Isnac, H. Aksit, O. Sen, N. Genc and I. Demirtas (2016). Isolation and identification of a new neo-clerodane diterpenoid from Teucrium chamaedrys L., Nat. Prod. Res. 30, 299-304

[39] C. Jimenez and R. Riguera (1994). Phenylethanoid glycosides in plants: Structure and biological activity, Nat. Prod. Rep. 1994, 591-606.

[40] Z. Xue and B. Yang (2016). Phenylethanoid glycosides: Research advances in their phytochemistry, pharmacological activity and pharmacokinetics, Molecules 21, 991.

[41] J. Heilmann, İ. Çalış, H. Kırmızıbekmez, W. Schühly, Ş. Harput and O Sticher (2000). Radical scavenger activity of phenylethanoid glycosides in FMLP stimulated human polymorphonuclear leukocytes: Structure-activity relationships, Planta Med. 66(8), 746-748.

[42] S.D. Marino, C. Festa, F. Zollo, F. Incollingo, G. Raimo, G. Evangelista and M. Iorizzi (2012). Antioxidant activity of phenolic and phenylethanoid glycosides from Teucrium polium L., Food Chem. 133, 21-28.

[43] Y. Dai, G. Han, S. Xu, Y. Yuan, C. Zhao and T. Ma (2020). Echinacoside suppresses amyloidogenesis and modulates F-actin remodeling by targeting the ER stress sensor PERK in a mouse model of alzheimer's disease, Frontiers in Cell and Developmental Biology 8, 1-20.

[44] J.B. Harborne (1966). Caffeic acid ester distribution in higher plants, Z. Naturforsch. 21b, 604-605.

[45] J.A. Pedersen (2000). Distribution and taxonomic implications of some phenolics in the family Lamiaceae determined by ESR spectroscopy, Biochemical Systematics and Ecology 28, 229-253.

[46] J.P. Alvarez, F Sáez-Royuela, E.G. Peña, A.L. Morante, A.V. Osés and J.M. Lorente (2001). Acute hepatitis due to ingestion of Teucrium chamaedrys infusions, Gastroenterol. Hepatol. 24, 240-243. 
[47] D. Polymeros, D. Kamberoglou and V. Tzias (2002). Acute cholestatic hepatitis caused by Teucrium polium (golden germander) with transient appearance of antimitochondrial antibody, J. Clin. Gastroenterol. 34, 100-101.

[48] R. Gagliano Candela, S. Rosselli, M. Bruno and G. Fontana (2020). A Review of the phytochemistry, traditional uses and biological activities of the essential oils of genus Teucrium, Planta Med. DOI 10.1055/a-1293-5768

[49] M.-E. Grafakou, C. Barda and H. Skaltsa (2020). Secondary metabolites of Teucrium species with toxic effects. In: Teucrium species: Biology and applications, Ed. Milan Stanković, Springer, pp 211-230.

[50] J.B. Harborne, F.A. Thomás Barberán, C. A. Williams and M. I. Gil (1986). A chemotaxonomic study of flavonoids from european Teucrium species, Phytochemistry 25, 2811-2816.

[51] A. Ulubelen, G. Topçu and U. Kolak (2005). Labiatae flavonoids and their bioactivity. In: studies in Natural Products Chemistry, ed: Atta-ur Rahman, Elsevier Science, Amsterdam, Netherlands, Vol. 30, pp 233-302.

[52] G. Valentini, B. Bellomaria and N. Arnold (1997). Essential oil of Teucrium creticum L. from Cyprus, J. Essent.Oil Res. 9: 649-652.

[53] M. Al-Masri, G. Omar, A. Taha, A. Abu Alsoud, E. Tawafsha, R. Basheer, M. Al-Akhras and R. Taradeh (2019). Antimicrobial activities of Teucrium creticum against reference microbial strains and multi-drug resistant bacteria isolated at an oncology, J. Advan. Microbiol. 17, 1-7.

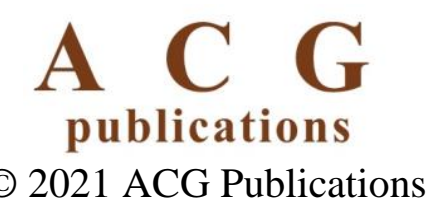

